\title{
THE POSSIBILITIES OF USING HEC-RAS SOFTWARE FOR MODELLING HYDRAULIC CONDITIONS OF WATER FLOW IN THE FISH PASS EXAMPLED BY THE POMIŁOWO BARRAGE ON THE WIEPRZA RIVER
}

\author{
Mateusz Hammerling'1, Natalia Walczak', Zbigniew Walczak², Paweł Zawadzki \\ 1 Department of Hydraulic and Sanitary Engineering, Poznań University of Life Sciences, Piątkowska 94A Str., \\ 60-649 Poznań, Poland, e-mail:mhammer@up.poznan.pl, natwal@wp.pl, pzaw@up.poznan.pl \\ 2 Institute of Construction and Geoengineering, Poznań University of Life Sciences, Piątkowska 94E Str., 60-649 \\ Poznań, Poland, e-mail: zbw@up.poznan.pl
}

Received: 2016.02 .04

Accepted: 2016.03.04

Published: 2016.04.01

\begin{abstract}
The aim of the article is to analyse hydraulic conditions of water flow in a fish pass. The test facility is part of the Pomiłowo barrage in the commune of Sławno, Poland. The authors applied HEC-RAS software for modelling hydraulic parameters of the water flow in the fish pass. The data from field measurements was implemented in the software and calculations of changes in the water table in the fish pass were made. The results confirmed the usefulness of HEC-RAS software for estimating hydraulic parameters of water flow in a fish pass. HEC-RAS software enables to take into account the parameters responsible for the phenomena accompanying the flow through a fish pass. Selecting mathematical model parameters (coefficients) should be preceded by a multidimensional analysis of the facility. More precise information on hydraulics, hydrology and biology of the test fish pass are also required.
\end{abstract}

Keywords: field measurements, fish pass, water table topology, HEC-RAS.

\section{INTRODUCTION}

Humans have used baffling facilities in riverbeds for hundreds of years. At first, people baffled rivers to build traps for fish, then to use the energy of flowing water, as well as for its retention. Each baffling structure imposes restriction on migration and high dams make it impossible [Kasperek and Wiatkowski 2008]. Baffles facilitated fishing, however, they made it difficult for fish to move upstream [Lubieniecki 2008]. Translocation of fish is very important from the perspective of aquatic ecosystem. Hindered migration reduces reproduction, which consequently contributes to the extinction of some species (including the European sea sturgeon and salmon in Poland). Migration of fish that undertake long-term or shortterm routes can be divided into three groups. The division depends on the objectives and includes feeding, wintering and spawning migrations. During a flood event, when water levels are high, fish swim down the river, which can be observed primarily in regulated rivers. When the water level decreases, fish migrate upstream [Lubieniecki 2008]. One of the methods for passing fish along riverbeds is to construct hydro-technical facilities, which not only perform technical functions to reduce the slope of watercourse bottom, but they also play a similar role to fish passes and/ or circulation channels. These are rapids with increased roughness [Radecki-Pawlik 2011, 2013].

Recently, old impoundments have been reproduced. They are used both for energy production and building new hydropower plants. It is particularly important that migration of fish and other aquatic organisms in both directions is taken into consideration in these projects [Armstrong et al. 2010]. The Regulation of the Minister of Environment of 20 April 2007 "on technical conditions to be met by hydraulic structures and their location" includes in chapter 2 the information on fish protection and the necessity of building fish 
passes. „18. Damming structures on rivers are equipped with facilities that ensure free passage of fish through an obstacle as long as it is justified by local conditions, and water tanks are shaped so as to leave refuges and spawning grounds for fish". For this purpose fish passes are applied.

Fish passes can be divided into fish passes of natural character, technical passes, locks for fish, and elevators [Hämmerling and Franczak 2012]. Natural fish passes are built of stones found in the immediate vicinity of the structure under construction. They include stone rapids otherwise known as stone ramps. The group of technical passes includes: chamber passes, vertical slot passes, passes with reverse current, eel passes, locks for fish and fish elevators [Lubieniecki 2008]. Chamber passes did not fully meet requirements, so they were modified into vertical slot passes [Mokwa 2007]. Modification of the opening size of vertical slot fish passes increased the effectiveness of migration facility in relation to fish migration offered by chamber fish passes. In addition, vertical slot fish passes are able to operate independently of the water table depth. For reverse current fish passes the outlet should be under water also in case of low water levels. This type of structure requires a considerable amount of water for smooth operation. Reverse current fish passes provide the highest usefulness for salmonidae species and barbells [Lubieniecki 2008]. Eel passes are adapted exclusively for the species. Eels are able to move through damp grass. In order to achieve the effect of natural vegetation, nylon brushes and branches are placed diagonally. As a result, eels are capable of moving against the current [Błachuta et al. 2010]. These structures are treated as additional facilities and placed near chamber or vertical slot passes [Lubieniecki 2008]. Locks for fish have a similar use like chamber locks for vessels on waterways. The structure consists of a large chamber, to which the inlet and outlet can be adjusted at the top and bottom positions. Fish elevators are used in areas where water level differences at the top and bottom positions are very significant. They do not occupy too much space and are designed for small and large fish species alike [Błachuta et al. 2010].

The construction of passes is another element widely studied by academics. The meandering fish pass is provided with chambers (modules) arranged modularly in an arbitrary manner. The material the modules are made of and their shape protect animals against being hurt. This type of fish pass functions well even if the water level is low [Mokwa 2010]. Another example is the lock fish pass, which as a result of design modifications produces hydraulically the flow conditions that meet criteria for biological stability of fish in a given area [Wyrębek 2013]. A fish pass is fully functional when each species of fish is able to pass through it easily. Therefore, it is important that a fish pass adjusts the flow velocity accordingly to even the smallest species. Due to the velocity, there will be provided conditions for migration of diadromous fish, as well as other particularly vulnerable species [Bojarski et al. 2005].

The literature provides a variety of studies related to fish pass. Kałuża and Tymiński (2013) demonstrated that vegetation found in fish passes helps in dispersing energy and reducing the velocity of flowing water below allowable values for ichtyofauna. The topic of fish pass velocity and hydraulics modelling has been raised in several publications e.g.: Bartnik et al. (2010), Książek et al. (2011). The publication by Bartnik examines a river section, which features a barrage facility. It includes a lock fish pass, a weir and a small power plant. Based on analyses carried out, the authors found that the velocity of water outgoing from the fish pass depends on hydraulic conditions existing in the facility and hydraulic characteristics of the main watercourse.

\section{METHODOLOGY}

The main objective of the article was to recreate hydraulic conditions of the water flow in the fish pass based on the mathematical model with the use of software. For modelling Hydrologic Engineering System-River Analysis System (HEC-RAS) software [Brunner 2010] was used to calculate water level topology over the entire length of the fish pass and average velocities in cross-sections. The results obtained were compared with field measurements. In order to obtain more accurate results of the water table topology the modifying parameters represented by the flow rate coefficient located in the slots between chambers of the fish pass and the coefficient associated with energy losses that result from narrowing and widening cross-sections were used. The field research was carried out at the Pomiłowo barrage on the Wieprza river $(\mathrm{km} \mathrm{49+305} \mathrm{in} \mathrm{West} \mathrm{Pomer-}$ ania, Sławno, Figure 1). 


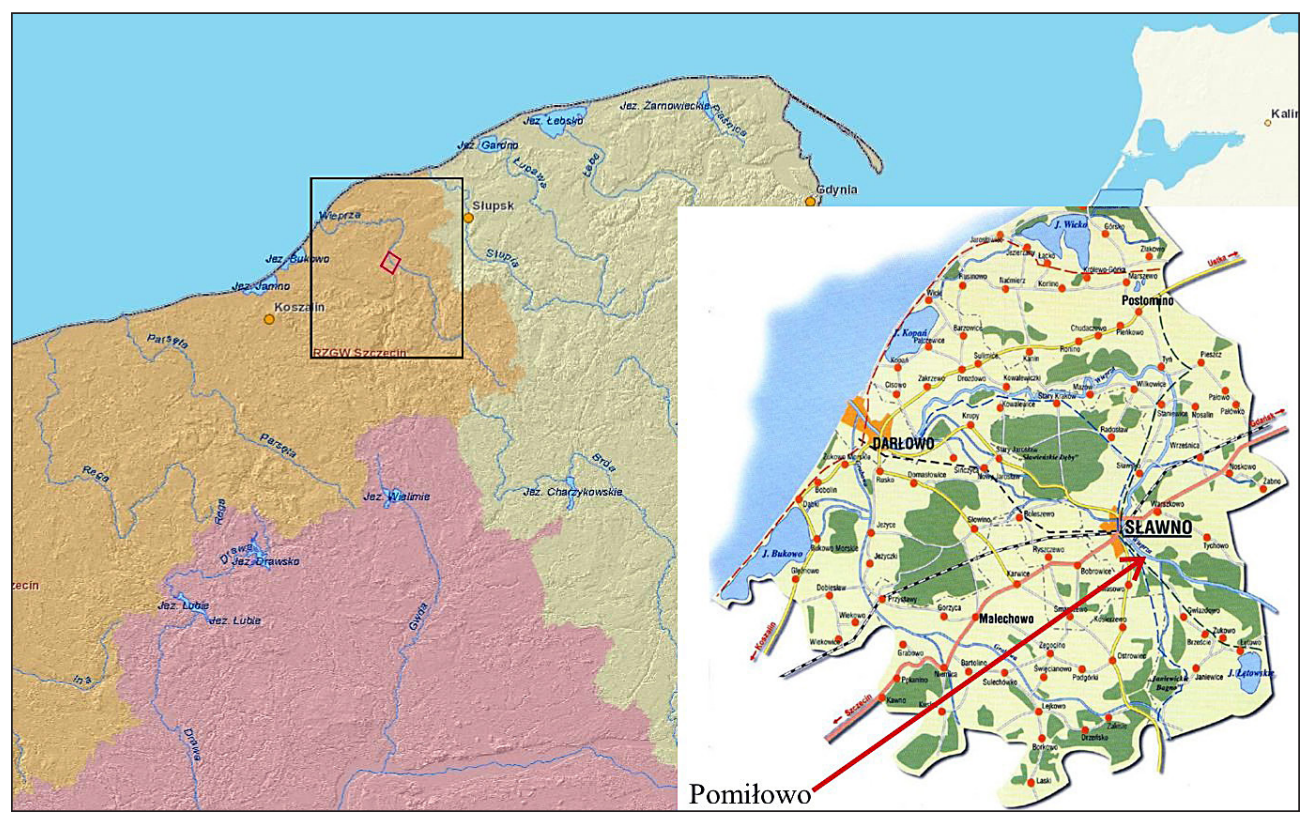

Figure 1. Map location facility - Pomiłowo (Program ochrony... 2009, www.kzgw.gov.pl)

a)

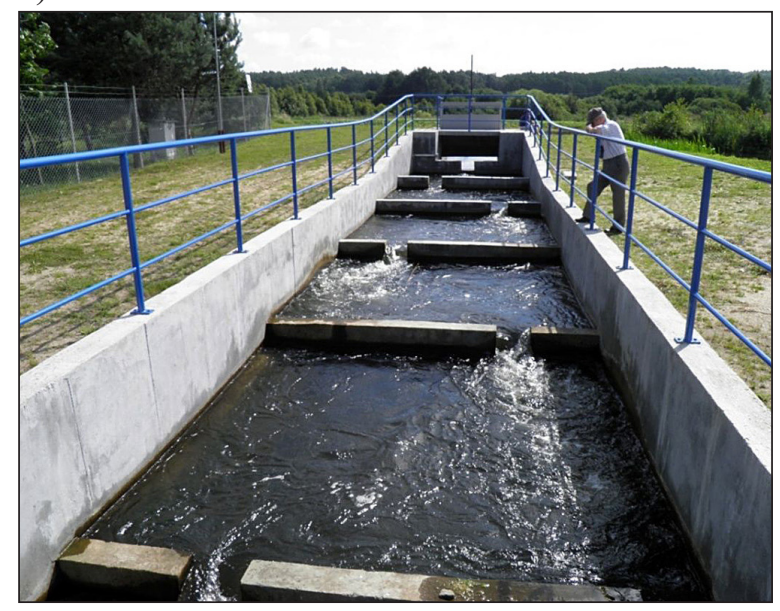

b)

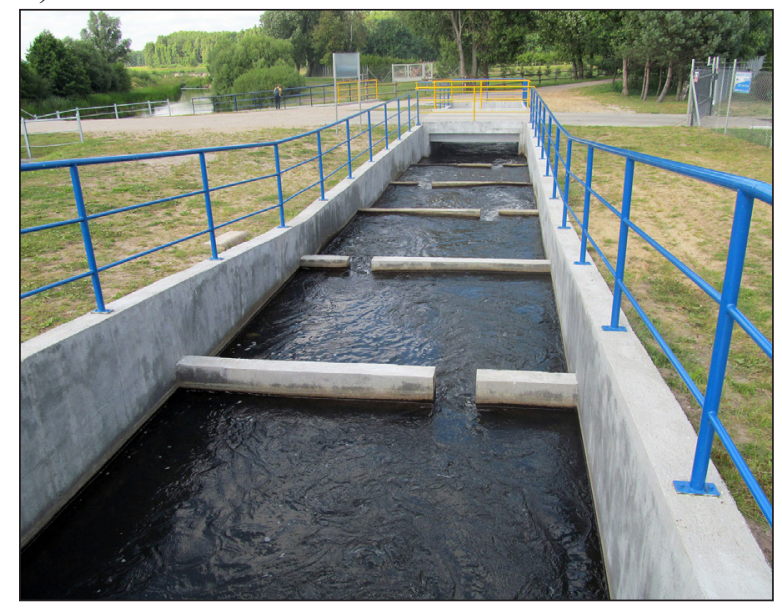

Figure 2. Fish pass view a) upstream of outlet b) central portion

The analysed fish pass (Figures $2 \mathrm{a}$ and $2 \mathrm{~b}$ ) has the shape of concrete-stone rapids and consists of 15 trapezoidal chambers. The structure is located at the weir. The fish pass is characterised by the following parameters: length $72.5 \mathrm{~m}$, bottom width $2.0 \mathrm{~m}$, width of the slot between chambers $0.35 \mathrm{~m}$, length of chambers $3.50 \mathrm{~m}$ [Franczak and Nawrot-Wicher 2011].

During the field research the water table ordinates were measured in all chambers at the inlet and outlet of the fish pass as well as hydraulic tests measuring the water flow depth and velocity in the fish pass. The velocity measurement in hydrometric verticals was carried out at the inlet of the fish pass and in a selected chamber of the facility (chamber 12). The measurement results were used to verify the simulation of the water table topology obtained from HEC-RAS. The software is based on the energy equation (Bernoulli's equation) for subsequent pairs of cross-sections [Brunner 2010].

$$
Z_{2}+Y_{2}+\frac{\alpha_{2} V_{2}^{2}}{2 g}=Z_{1}+Y_{1}+\frac{\alpha_{1} V_{1}^{2}}{2 g}+h_{e}
$$

where: $Z_{1}, Z_{2}-$ channel bottom height to the reference level,

$Y_{1}, Y_{2}$ - water depth at the cross-section, $V_{1}, V_{2}-$ average velocity values (total flow rate / total flow area), $\alpha_{1}, \alpha_{2}-$ velocity coefficient, $g$ - acceleration due to gravity, $h_{\mathrm{e}}$ - energy losses. 
Energy losses $\left(h_{\mathrm{e}}\right)$ formed between two crosssections include friction losses as well as narrowing and widening losses. They can be described by the following equation:

$$
h_{e}=L \overline{S_{f}}+C\left|\frac{\alpha_{2} V_{2}^{2}}{2 g}-\frac{\alpha_{1} V_{1}^{2}}{2 g}\right|
$$

where: $L$ - flow rate between two consecutive cross-sections, $\overline{S_{f}}-$ slope between two cross-sections, $C$ - contraction or expansion coefficient.

Distribution coverage of the weighted distance can be calculated using the following formula:

$$
L=\frac{L_{l o b} \overline{Q_{l o b}}+L_{c h} \overline{Q_{c h}}+L_{r o b} \overline{Q_{r o b}}}{\overline{Q_{l o b}}+\overline{Q_{c h}}+\overline{Q_{r o b}}}
$$

where: $L_{\mathrm{lob}}, L_{\mathrm{ch}}, L_{\mathrm{rob}}-$ lengths specified in the flow direction for the left floodplain, main riverbed and right floodplain.

$\overline{Q_{l o b}}, \overline{Q_{c h}}, \overline{Q_{\text {rob }}}$ - arithmetic average of flows between cross-sections for the left floodplain, main riverbed and right floodplain.

Flow losses related to contraction and expansion in HEC-RAS can be calculated using the following formula:

$$
h_{c e}=C\left|\frac{\alpha_{1} V_{1}^{2}}{2 g}-\frac{\alpha_{2} V_{2}^{2}}{2 g}\right|
$$

where: $C$ - contraction and expansion coefficient.

When dimensioning the fish pass, the following correlation defining the flow rate is used $Q$ :

$$
Q=\frac{2}{3} \mu \cdot s \sqrt{2 g} h^{3 / 2}
$$

Flow rate coefficient $\mu$ :

$$
\mu=\frac{Q}{\frac{2}{3} s \sqrt{2 g} h^{\frac{3}{2}}}
$$

where: $Q$ - volumetric flow rate, $\mathrm{m}^{3} / \mathrm{s}$;

$\mu$ - water flow coefficient, - ;

$s$ - slot width, m,

$h$ - water head.

HEC-RAS software calculates the flow rate passing through a slot in the fish pass with the use of correlation between the flow rate and the overflow:

$$
Q=C_{1} H^{\frac{3}{2}}
$$

where: $Q$ - flow rate, $\mathrm{m}^{3} / \mathrm{s}$;

$L$ - overflow length (slot length), m;

$H$ - energy head line, m;

$C_{1}$ - flow rate coefficient, -.

The value of coefficient $C_{l}$ is determined empirically from the correlation:

$$
C_{1}=\frac{2}{3} \mu_{r} \sqrt{2 g}
$$

After the transformation we obtain the correlation:

$$
\mu_{r}=\frac{3}{2} \frac{C_{1}}{\sqrt{2 g}}
$$

In order to achieve more accurate results of the water table topology in HEC-RAS, it is possible to take into account coefficients responsible for geometry of the chamber cross-section (contraction or expansion values). The software assumes that the flow narrows when the velocity of water flowing to the adjacent cross sections is higher than the inlet velocity. Analogously, when the velocity of flowing water is higher than the outlet velocity, the software assumes that the cross-section widens. Table 1 shows contraction or expansion coefficients of the cross-section for subcritical flow resulting from its geometry.

Maximum values for both coefficients are 1.0, however, they apply only to the supercritical flow.

Table 1. Coefficient $C$ (eq. 4) dependent on slot geometry (Chaudhry 2008, Brunner 2010)

\begin{tabular}{|l|c|c|}
\hline \multirow{2}{*}{ Geometry descriptions } & \multicolumn{2}{|c|}{ Coefficient (Eq. 4) } \\
\cline { 2 - 3 } & Contraction $C_{\mathrm{C}}$ & Expansion $C_{\mathrm{E}}$ \\
\hline No transition loss computed & 0 & 0 \\
\hline Gradual transitions & 0.1 & 0.3 \\
\hline Typical bridge sections & 0.3 & 0.5 \\
\hline Abrupt transitions & 0.6 & 0.8 \\
\hline
\end{tabular}

\section{RESULTS}

During the field research water table values in particular chambers of the fish pass were measured (Figure 3). Subsequently, geometry data of the structure was entered into HEC-RAS and the water flow in the fish pass was modelled. Calculations assumed the roughness coefficient equal to $0.03 \mathrm{~m}^{-1 / 3} \mathrm{~s}$. The water table ordinate known from measurements, equal to $17.68 \mathrm{~m}$ meters above the sea level, was assumed as the bottom boundary condition. The top boundary condition of the 


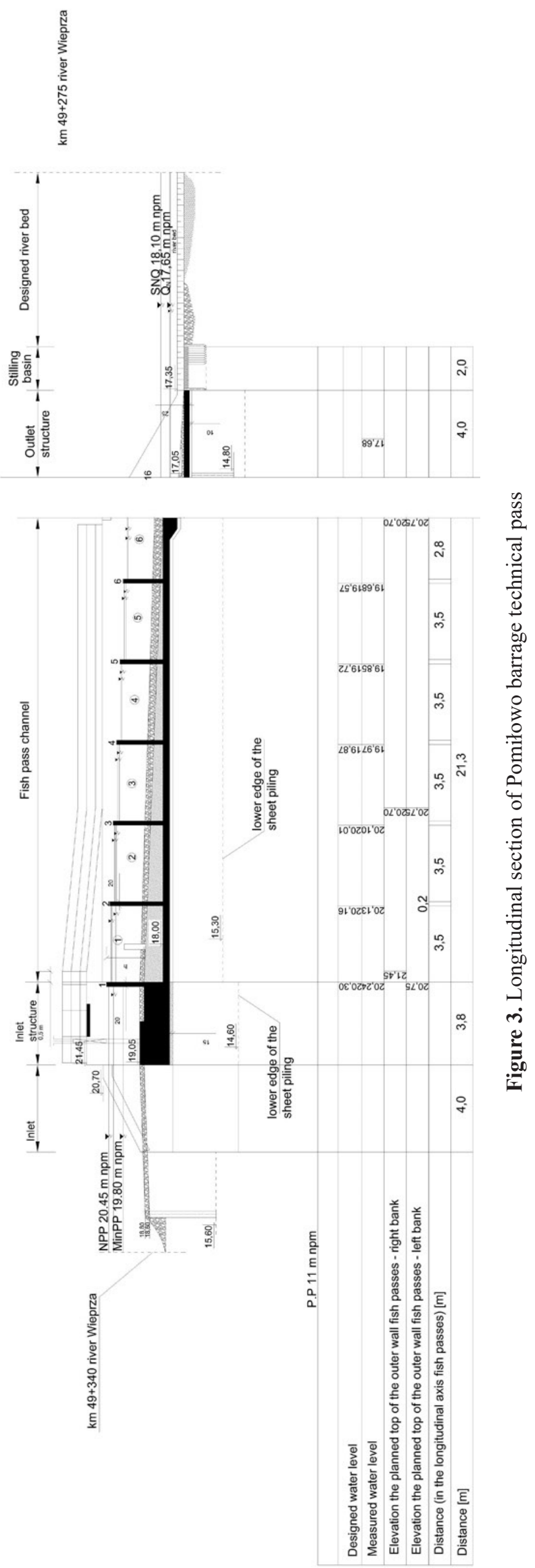


water flow rate was measured during the field research $\left(\mathrm{Q}=0.754 \mathrm{~m}^{3} / \mathrm{s}\right)$.

Figure 3 shows the water table topologies along the entire length of the fish pass determined during the field research and then designed. The analysis of the water table topologies leads to the observation that there are small differences in the table levels in particular chambers of the fish pass. The next step was to simulate the water table topology using HEC-RAS software. Additionally, the simulations included the flow rate coefficient $C_{1}$ (in the slot), whose value changed within the

Table 2. Comparing measured and calculated (HEC-RAS) water tables

\begin{tabular}{|c|c|c|c|c|c|c|c|}
\hline $\begin{array}{l}\text { Distance } \\
{[\mathrm{m}]}\end{array}$ & $\begin{array}{l}\text { Number of } \\
\text { chambers }\end{array}$ & $\begin{array}{c}\text { Measured } \\
\text { level [m] }\end{array}$ & $\begin{array}{c}\text { Calculated level } \\
{[\mathrm{m}]}\end{array}$ & $\begin{array}{c}\text { Distance } \\
{[\mathrm{m}]}\end{array}$ & $\begin{array}{l}\text { Number of } \\
\text { chambers }\end{array}$ & $\begin{array}{c}\text { Measured } \\
\text { level [m] }\end{array}$ & $\begin{array}{c}\text { Calculated level } \\
{[\mathrm{m}]}\end{array}$ \\
\hline 64.80 & Fich nacs inlet & 20.24 & 20.26 & & & & \\
\hline 61.80 & Fisn pass iniet & 20.24 & 20.26 & & & & \\
\hline 61.60 & \multirow{5}{*}{1} & 20.13 & 20.14 & 32.00 & \multirow{5}{*}{9} & 19.21 & 19.20 \\
\hline 60.73 & & 20.13 & 20.14 & 31.13 & & 19.21 & 19.20 \\
\hline 59.85 & & 20.13 & 20.14 & 30.25 & & 19.21 & 19.20 \\
\hline 58.97 & & 20.13 & 20.14 & 29.37 & & 19.21 & 19.20 \\
\hline 58.10 & & 20.13 & 20.14 & 28.50 & & 19.21 & 19.20 \\
\hline 57.90 & \multirow{5}{*}{2} & 20.10 & 20.03 & 28.30 & \multirow{5}{*}{10} & 19.04 & 19.07 \\
\hline 57.03 & & 20.10 & 20.03 & 27.43 & & 19.04 & 19.07 \\
\hline 56.15 & & 20.10 & 20.03 & 26.55 & & 19.04 & 19.07 \\
\hline 55.27 & & 20.10 & 20.03 & 25.67 & & 19.04 & 19.07 \\
\hline 54.40 & & 20.10 & 20.03 & 24.80 & & 19.04 & 19.07 \\
\hline 54.20 & \multirow{5}{*}{3} & 19.97 & 19.91 & 24.60 & \multirow{5}{*}{11} & 18.88 & 18.95 \\
\hline 53.33 & & 19.97 & 19.91 & 23.73 & & 18.88 & 18.95 \\
\hline 52.45 & & 19.97 & 19.91 & 22.85 & & 18.88 & 18.95 \\
\hline 51.57 & & 19.97 & 19.91 & 21.97 & & 18.88 & 18.95 \\
\hline 50.70 & & 19.97 & 19.91 & 21.10 & & 18.88 & 18.95 \\
\hline 50.50 & \multirow{5}{*}{4} & 19.85 & 19.80 & 20.90 & \multirow{5}{*}{12} & 18.72 & 18.80 \\
\hline 49.63 & & 19.85 & 19.80 & 20.03 & & 18.72 & 18.80 \\
\hline 48.75 & & 19.85 & 19.80 & 19.15 & & 18.72 & 18.80 \\
\hline 47.87 & & 19.85 & 19.80 & 18.27 & & 18.72 & 18.80 \\
\hline 47.00 & & 19.85 & 19.80 & 17.40 & & 18.72 & 18.80 \\
\hline 46.80 & \multirow{5}{*}{5} & 19.68 & 19.69 & 17.20 & \multirow{5}{*}{13} & 18.54 & 18.60 \\
\hline 45.93 & & 19.68 & 19.69 & 16.33 & & 18.54 & 18.60 \\
\hline 45.05 & & 19.68 & 19.69 & 15.45 & & 18.54 & 18.60 \\
\hline 44.17 & & 19.68 & 19.69 & 14.57 & & 18.54 & 18.60 \\
\hline 43.30 & & 19.68 & 19.69 & 13.70 & & 18.54 & 18.60 \\
\hline 43.10 & \multirow{4}{*}{6} & 19.6 & 19.57 & 13.50 & \multirow{4}{*}{14} & 18.38 & 18.54 \\
\hline 42.23 & & 19.6 & 19.57 & 12.63 & & 18.38 & 18.54 \\
\hline 41.35 & & 19.6 & 19.57 & 11.75 & & 18.38 & 18.54 \\
\hline 40.47 & & 19.6 & 19.57 & 10.87 & & 18.38 & 18.54 \\
\hline 39.60 & \multirow{5}{*}{7} & 19.47 & 19.45 & 9.80 & \multirow{5}{*}{15} & 18.16 & 18.39 \\
\hline 39.40 & & 19.47 & 19.45 & 8.93 & & 18.16 & 18.39 \\
\hline 38.53 & & 19.47 & 19.45 & 8.05 & & 18.16 & 18.39 \\
\hline 37.65 & & 19.47 & 19.45 & 7.17 & & 18.16 & 18.39 \\
\hline 36.77 & & 19.47 & 19.45 & 6.30 & & 18.16 & 18.39 \\
\hline 35.90 & \multirow{6}{*}{8} & 19.33 & 19.31 & & & & \\
\hline 35.70 & & 19.33 & 19.31 & & & & \\
\hline 34.83 & & 19.33 & 19.31 & & & & \\
\hline 33.95 & & 19.33 & 19.31 & & & & \\
\hline 33.07 & & 19.33 & 19.31 & & & & \\
\hline 32.20 & & 19.33 & 19.31 & & & & \\
\hline
\end{tabular}


range of 1.4-2.6. The closest simulation results of the water table topology, in comparison to the values measured in the field, were obtained for the coefficient 1.75. Table 2 shows the calculated values of water table ordinates.

By analysing Table 2 it can be observed that differences between the measured and calculated levels of the water table decreased consistently as it proceeded towards the outlet of the fish pass. The biggest difference in the water table was obtained for chamber 15 and it was equal to $0.23 \mathrm{~m}$, and the smallest ones were calculated for chambers 5 and 1 and they were equal to $0.01 \mathrm{~m}$. Similar correlations can be noticed in the subsequent calculation schemes that employ different variants of coefficients.
The calculations also included the impact of different values of the contraction coefficient $C$ (eq. 4) from 0.1 to 0.6 and the expansion coefficient from 0.3 to 0.8 . Changes in coefficients did not significantly affect the results of calculations of the water table topology. The adoption of different values of coefficients resulted from the location of a given cross-section along the length of the fish pass. The coefficients corresponding to sudden change in a cross section were implemented in the immediate vicinity of the partition, and the coefficients corresponding to mild change in a cross-section were adopted in the middle of the chamber. Graphical representation of the simulation results are shown in Figure 4.

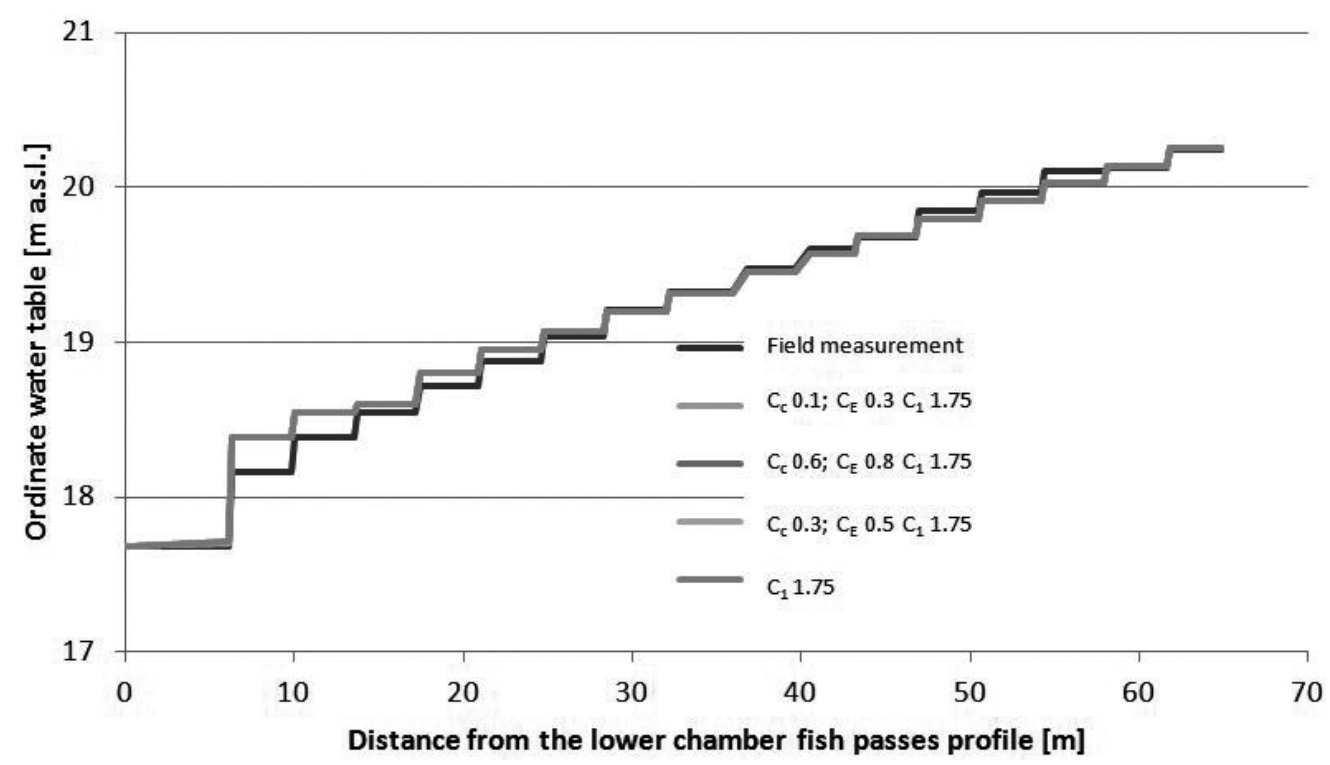

Figure 4. Difference between measured and calculated water table on length of fish-pass: $C_{\mathrm{C}}$ - contraction coefficient (eq. 4), $C_{\mathrm{E}}$ - expansion coefficient (eq. 4), $C_{1}$ - flow rate coefficient

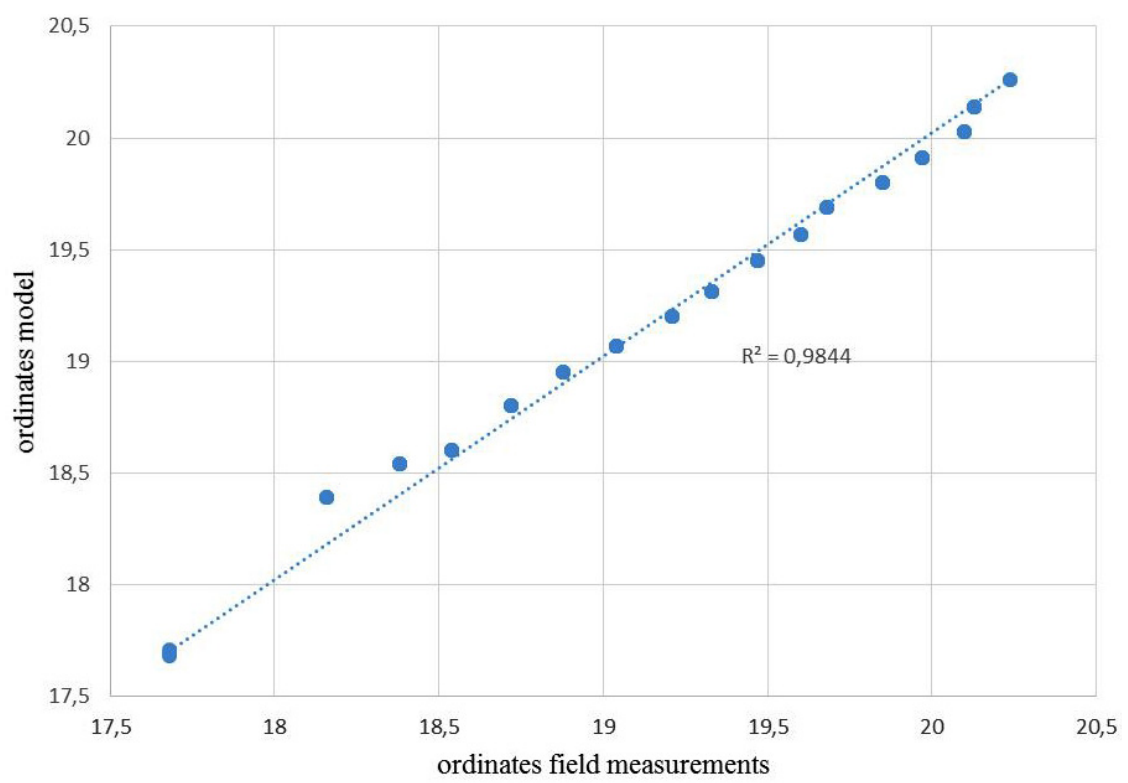

Figure 5. Comparing measured and calculated (HEC-RAS) water tables 
The correctness of adoption of the water flow coefficient for accurate water table topology mapping is shown in Figure 5. High compatibility of the measured and modelled water table ordinates confirms the value of the correlation coefficient $\mathrm{R}^{2}=0.99$.

Modelling capabilities of the water flow rate in the fish pass was also checked. HEC-RAS calculates velocity values as averages for a given cross-section. Changing the narrowing and widening coefficients did not alter the calculated average velocities. The velocity calculated in the cross-section located just outside the inlet the fish pass was $0.18 \mathrm{~m} / \mathrm{s}$ and the measured value was 0.2 $\mathrm{m} / \mathrm{s}$. The velocity measurement was also carried out in three verticals in chamber 12 [Hämmerling 2015]. The average flow velocity was $0.20 \mathrm{~m} / \mathrm{s}$, and its value calculated with the use of HEC-RAS was $0.24 \mathrm{~m} / \mathrm{s}$ in the hydrometric vertical located axially in the fish pass.

\section{CONCLUSIONS}

The article presents the results of field and modelled research of the water table topology and velocity distributions carried out in the fish pass located at the Pomiłowo barrage on the Wieprza river. Based on the field research, HEC-RAS recreated geometry of the fish pass and calculations (water table topology) of hydraulic parameters of the water flow in the fish pass were made. Applying HEC-RAS for modelling the water table topology in the fish pass requires uploading specified coefficients: e.g. water flow, contraction or expansion. Additionally, it must be remembered that the software used is one-dimensional and works best for longer river distances. With much longer distances it is possible to install some obstacles in the form of hydraulic structures (bridges, culverts), but they occur at a considerable distance from each other. Considering the fish pass, HEC-RAS treats each chamber as a separate hydraulic structure, and in connection with a slight distance the obtained results may not be explicitly accepted. Summing up, modelling of the water table topology is a sophisticated issue, however, the authors have noticed a significant potential for HEC-RAS software to analyse hydraulics of the fish pass. Therefore, there is a need of analysing the possible use of the software for further studies of this type.

\section{REFERENCES}

1. Armstrong G., Aprahamian M., Fewings G., Gough P., Reader N., Varallo P. 2010. Environment Agency Fish Pass Manual. Environment Agency, Bristol.

2. Bartnik W., Książek L., Wyrębek M. 2010. Hydrauliczne warunki występowania prądu wabiącego dla przepławek ryglowych. Polska Akademia Nauk, Kraków, No. 9, 123-132.

3. Błachuta J., Rosa J., Wiśniewolski W., Zgrabczyński W. 2010. Ocena potrzeb i priorytetów, udrożnienia ciągłości morfologicznej rzek w kontekście osiągnięcia dobrego stanu i potencjału części wód w Polsce. Biuro Projektów Wodnych Melioracji i Inżynierii Środowiska „Biprowodmel” Sp, z o,o, w Poznaniu, Poznań.

4. Bojarski A., Jeleński J., Litewka T, Wyżga B, Zalewski J. 2005. Zasady dobrej praktyki w utrzymywaniu rzek i potoków górskich. Wydawca Ministerstwo Środowiska Departament Zasobów Wodnych, Warszawa.

5. Brunner G. 2010. HEC-RAS, River Analysis System Hydraulic Reference Manual. U,S, Army Corps of Engineers Institute For Water Resources Hydrologic Engineering Center, Davis.

6. Chaudhry M.H. 2008. Open-channel flow. Springer Science \& Business Media.

7. Franczak D., Nawrot-Wicher E., 2011. Instrukcja gospodarowania wodą (projekt). Biuro Studiów i Projektów Budownictwa Wodnego Hydroprojekt, Poznań.

8. Hämmerling M., Franczak D. 2012. Scenariusze rozwoju i badania hydrauliczne przepławek dla ryb. In: K. Borodako, M. Nowosielski (Eds.) Foresight w przedsiębiorstwach, Nauka - Technologia - Wdrożenie. Wydawnictwo IZ, Poznań, 33-44.

9. Hämmerling M. 2015. Hydrologiczne i hydrauliczne charakterystyki przepławki dla ryb stopnia wodnego Pomiłowo na rzece Wieprzy. In: T. Kałuża i M. Hämmerling (Eds.) Problemy projektowania i eksploatacji przepławek dla ryb. Monografia. Bogucki Wydawnictwo Naukowe.

10. Kałuża T,, Tymiński T. 2013. Effect of Vegetation on Flow Conditions in the "Nature-like" Fishways. Rocznik Ochrony Środowiska, Vol. 15, 348-360.

11. Kasperek R,, Wiatkowski M. 2008. Terenowe badania funkcjonowania przepławki dla ryb na zbiorniku Michalice. Rocznik Ochrona Środowiska, Vol. 10, 613-622.

12. Książek L., Strużyński A., Leja M. 2011. Modelowanie fizyczne i numeryczne przepływu wody w przepławce biologicznej. Acta Scientarium Polonorum, 10(4), 17-30.

13. Lubieniecki B. 2008. Przepławki i drożność rzek. 
Wydawnictwo Instytutu Rybactwa Śródlądowego, Olsztyn.

14. Mokwa M. 2007. Przepławki dla ryb na stopniach regulacyjnych potoków górskich. Polska Akademia Nauk, Kraków, 4(2), 279-287.

15. Mokwa M. 2010. Obliczenia hydrauliczne przepławek dla ryb. Acta Scientarium Polonorum, 9(2), 43-58.

16. Program ochrony środowiska dla gminy Sławno,
2009. http://ug.slawno.ibip.pl/public/get file contents.php?id=205222, Nov. 2015.

17. Radecki-Pawlik A. 2011, 2014. Hydromorfologia rzek i potoków górskich. Wydawnictwo Uniwersytetu Rolniczego w Krakowie.

18. Wyrębek M. 2013. Przepławki ryglowe, Jako element przywróceni ciągłości korytarz ekologicznego rzek silnie zmnienionych. Infrastruktura I Ekologia Terenów Wiejskich, 3(I). 